\title{
Earthquake Damage to Industrial Facilities and Development of Seismic and Vibration Control Technology *
}

\author{
Kohei SUZUKI $^{* *}$ \\ ** Professor Emeritus, Vice President of Open University, \\ Tokyo Metropolitan University, \\ 1-1 Minami-osawa, Hachioji, Tokyo, 192-0397, Japan \\ E-mail: k-suzuki@ecomp.metro-u.ac.jp
}

\begin{abstract}
This paper reviews the situations and features of earthquake damage to industrial facilities, manufacturing companies, energy supply facilities, and mechanical structures and installations in Japan, and traces trends of countermeasure technology developed focusing on earthquake resistance and vibration control. In Japan, with the 1964 Niigata earthquake as the turning point, earthquake damage to industrial facilities became a social problem. With power stations being constructed in the 1960s, it also became an important technological policy to establish seismic design method for nonbuilding structures such as equipment and piping systems related to nuclear power. The Kobe earthquake in 1995 damaged production companies including leading manufacturers so extensively that it brought a new focus to seismic considerations. We studied the damage to typical equipment and installations and, based on this experience, investigated the features of damage modes to industrial facilities and machinery and considered corresponding technical measures. We present some examples and discuss progressive trends in seismic and vibration control technology following the Kobe earthquake. In particular, we focus on the new seismic design code for high-pressure gas facilities and the development of seismic and vibration control dampers and their applications.
\end{abstract}

Key words: Earthquake Damage, Industrial Facility, Seismic Design, Vibration Control, Seismic Damper

\section{History of Earthquake Damage to Industrial Facilities}

The 1964 Niigata earthquake focused attention on social problem arising from industrial facilities including companies related to the manufacturing industry. In addition to large-scale damage to plant facilities of Niigata Tekkoh Co., the large-scale heavy oil tanks of Showa Oil Co. burned continuously for 15 days. Fig. 1 shows the photo at that time. Power stations, coal mines, gas supply facilities, and factories were heavily damaged in the United States, China, and other countries due to frequent large earthquakes from the 1970s to the 1990s.

In Japan, particularly, the Kobe earthquake (Hanshin- Awaji earthquake) on January 17, 1995 caused destructive damage to a tremendous number of manufacturing companies ranging from large companies such as Kobe Steel, Mitsubishi Heavy Industries, Kawasaki Heavy Industries, and Sumitomo Rubber Industries, to small and medium-size companies. 
The Niigata-Chuetsu earthquake occurred in Niigata Prefecture in October 2004, 40 years after the earlier Niigata earthquake causing great damage due to landslides. Factory facilities were seriously damaged in Ojiya City and other locations. Table 1 summarizes trends in earthquake damage to industrial facilities in Japan.

There are many reports on overseas industrial facilities. The San Fernando earthquake in the vicinity

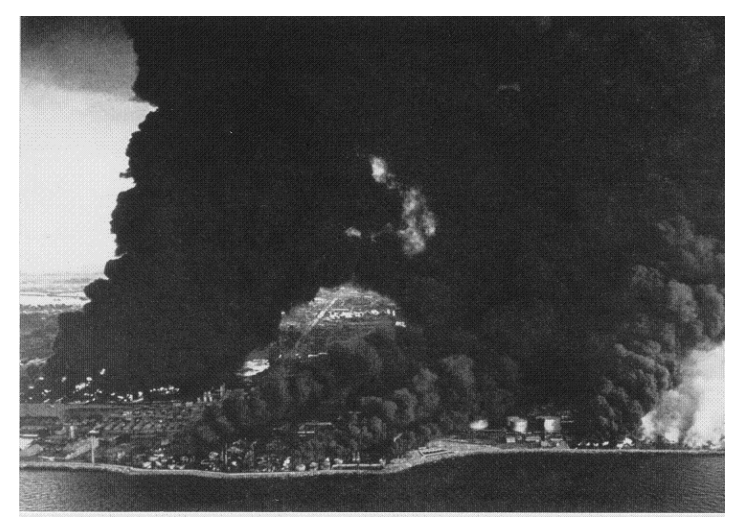

Fig. 1. Petroleum complex conflagration due to the 1964 Niigata Earthquake.

of Los Angeles in 1971 extensively damaged lifeline systems including power, gas, and water lines. Substation equipment, piping, and tanks of these lifelines were seriously damaged. The Tang-shan earthquake close to Beijing in China in 1976 seriously damaged or destroyed the heavy-industry zone and coal mines in its vicinity. The 1989 Loma Prieta earthquake striking San Francisco and the 1994 Northridge earthquake striking Los Angeles area damaged factories and energy supply facilities. The Kocaeli (Turkey) and Chi-chi (Taiwan) earthquakes in 1999 seriously damaged petroleum complexes and thermal power stations.

Table 1. Typical earthquake damage to industrial facilities in Japan.

\begin{tabular}{|c|c|c|}
\hline & Earthquakes & Typical damage \\
\hline \multirow[t]{4}{*}{1960} & \multirow[t]{2}{*}{ Niigata EQ (1964) } & - Destructive damage on Industrial area \\
\hline & & - Long-term fire in petroleum refinery \\
\hline & \multirow[t]{4}{*}{ Tokachi-oki EQ (1968) } & - Damage on large scale machineries \\
\hline & & - Damage on power stations and sub stations \\
\hline \multirow[t]{2}{*}{1970} & & - Breakage and pulling out of anchored structures \\
\hline & & - Damage on lifeline systems \\
\hline \multirow{3}{*}{1980} & \multirow[t]{3}{*}{ Miyagi ken-oki EQ (1978) } & - Damage on underground equipments and piping \\
\hline & & - Fire of thermal power station and petroleum tanks \\
\hline & & - Fire-induced damage of large tank due to sloshing \\
\hline \multirow{2}{*}{1990} & Nihonkai-Chubu EQ (1983) & - Long-term stoppage of power and gas supply \\
\hline & \multirow[t]{4}{*}{ Hyogoken-nanbu (Kobe) EQ (1995) } & - Destructive damage on heavy industries \\
\hline \multirow{4}{*}{2000} & & - Stoppage of product transport \\
\hline & & - Serious damage on medical/radioactive equipments \\
\hline & & - Long-term damage on thermal plant structures \\
\hline & Niigata-Chuetsu EQ (2004) & - Destruction of port facilities \\
\hline
\end{tabular}

\section{Earthquake Damage to Mechanical Installations and Equipment}

This chapter describes earthquake damage to factory installations and equipment and industrial energy facilities related to electric power, gas, and petroleum referencing past reports on damage by the Kobe earthquake, etc. to compare it to that to construction and civil engineering structures and installations.

(1) Structures in industrial facilities vary widely from flexible piping to rigid machining tools, and from small precision equipment to large cranes. Damage modes are thus highly versatile.

(2) Most structures and equipment are installed in factory buildings or support structures suffering earthquake force indirectly through these structures rather than directly from the 
ground. Earthquake damage severity to mechanical systems and patterns largely depend on seismic intensity in support structures. Serious damage to elevators and escalators is typical. (3) Most machine installations have specific functions, including manufacturing precision, number of revolutions, production efficiency, and supply capacity. The degree of structural damage may thus appear minor, but if a machine cannot perform the requested function, it is essentially out of commission. Functional failure is thus more important than structural failure. Information technology (IT)-related and medical equipment are typical.

(4) Due to recent industrial advances, a specific mechanical system rarely operates as a single unit, and large numbers of equipment and installations make up a production complex. If one important element of this complex is damaged, the production line stops even though most elements are undamaged. Damage assumptions must thus be understood in terms of the entire system.

What damage modes do individual installations and equipment demonstrate? If dynamic factors are classified and representative ones are determined, the following groupings are possible;

(1) Overturning of vertical structures with high center of gravity (machine tools, medical equipment, etc.)

(2) Overturning movement due to the breakage of anchor bolts (machine tools, substation installations, tanks, etc.)

(3) Falling with the destruction or damaged to factory buildings containing installed or stored equipment and their support structures (boilers, cranes, elevators, etc.)

(4) Destruction of equipment due to resonant vibration with support structures (cranes, and roof equipment)

(5) Inclination, deformation, or flooding due to ground liquefaction or support foundation damage (container cranes, piping, pumps, etc.)

(6) Buckling of containment vessels due to sloshing of fluid contents and explosion or burning flammable materials (tanks, etc.)

Typical damage is shown in Figs.2-8. Differences in damage modes such as in (1) to (6) above are due to the interaction of many factors, but it is important to note that they depend largely on the action modes of earthquake motion acting on structures described as below.

1. Inertia force of earthquake vibration

2. Relative displacement and deformation

3. Resonance response to support structures and buildings

4. Ground liquefaction and flow

5. Sloshing

3. Damage to Mechanical System Installations, Dangerous Facilities, and Gas Manufacturing Installations in Lifelines

The following damage to mechanical system installations, petro-chemical facilities, and gas manufacturing installations in lifelines were typical in the Kobe earthquake.

\subsection{Power Installations}

Damage was notable in boilers in power generation installations, and transformers and circuit breakers in substation installations. Oil storage tanks, piping, and expansion joints were damaged by ground liquefaction in gas turbine power stations. In thermal power

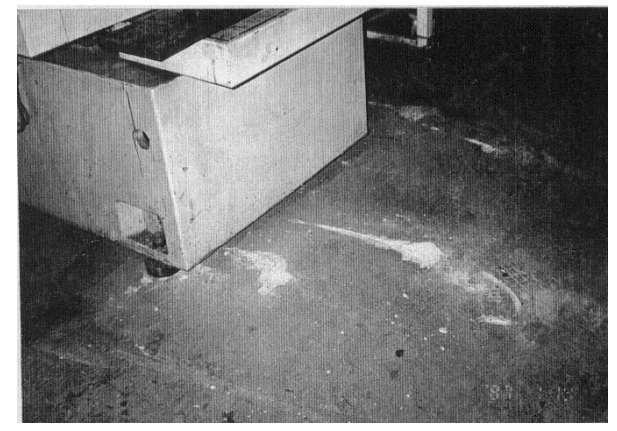

Fig. 2. Sliding of machine due to breakage of anchor bolt. 


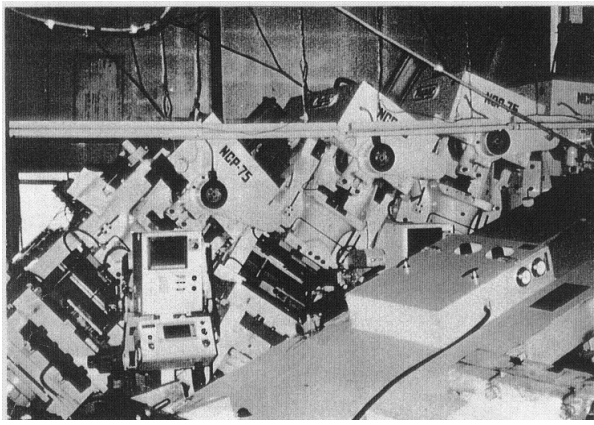

Fig. 3. Turnover of press machines.

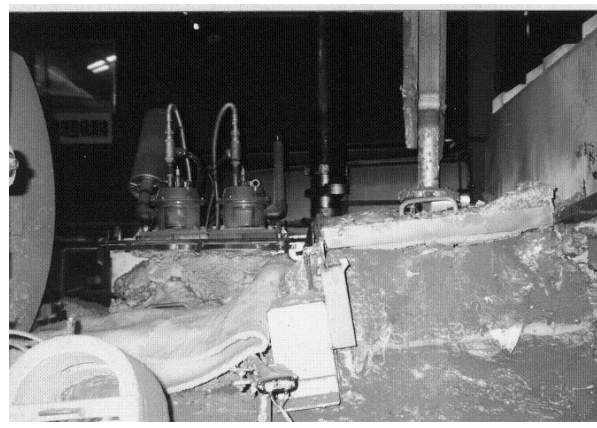

Fig. 5. Overflow of melted aluminum alloy from pool in the machine.

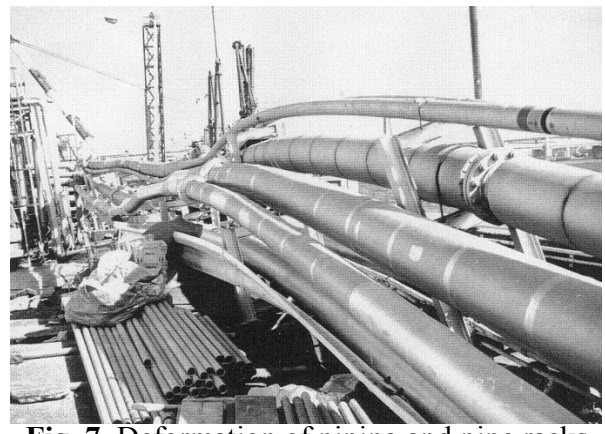

Fig. 7. Deformation of piping and pipe racks

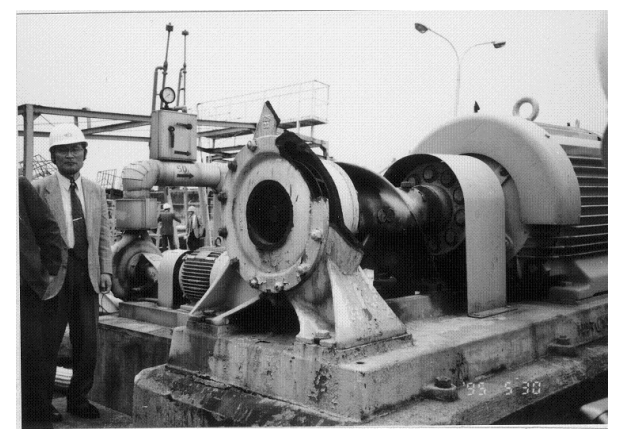

Fig. 4. Breakage of centrifugal pump casing.

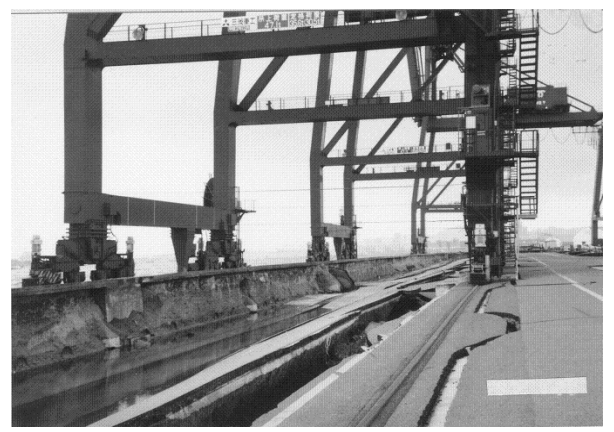

Fig. 6. Buckling and deformation of container crane leg.

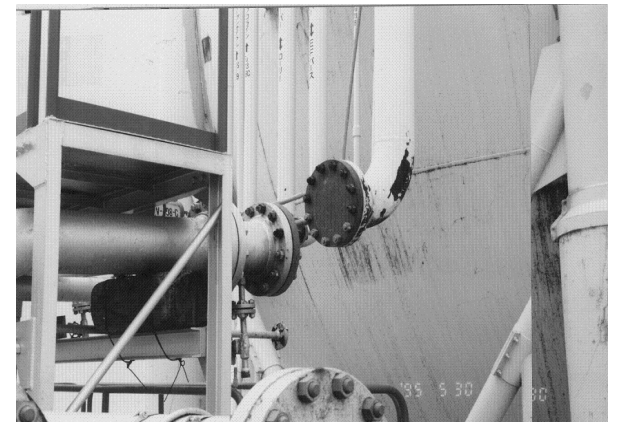

Fig. 8. Breakage of piping flange connections

stations, the fracture and deformation of the centers rest for large power generation boilers were notable. Steel beam support structures of boilers were deformed, and main steam tubes and water supply pumps were damaged. A Power Generation Technology Association took up the earthquake-resistance of LNG tanks and boiler structures for thermal power generation as a project of universities and companies in 1996, conducting excitation experiments using large shaking table on LNG tanks for the sloshing due to liquefaction and large ground displacement. It also conducted vibration experiments on boilers to validate the earthquake- resistance of boiler connecting devices.

\subsection{Telegraph and Telephone Installations}

With commercial power out-of-service due to earthquakes, power was not supplied to switchboards because emergency batteries has been destroyed. Damage to fuel water supply pipes of the emergency power generation system caused power to be supplied by emergency batteries, but the switchboard stopped due to excessive discharge, putting 285,000 transmission and reception lines out of service.

\subsection{Gas Supply Installations}

Gas supply was stopped mainly by leakage from pressurized pipings downstream. A large number of screw joints that were damaged had been buried 20 years ago or more. 


\subsection{Petro-Chemical Facilities}

Tanks and their piping were dynamically destroyed by ground liquefaction generated following the earthquake motion and large-scale ground movement, not by the earthquake motion itself, and subsequent differential settlement of ground, destruction, and lateral movement of shore protection. Tanks tipped due to ground movement as shown in Fig.9. Many tanks were damaged by buckling and deformation of their lateral walls as shown in Fig.10.

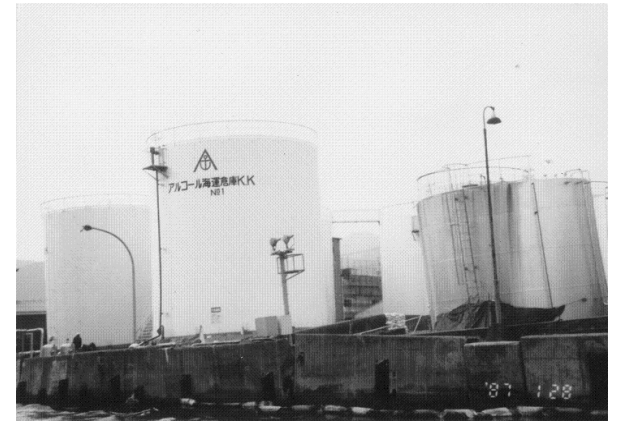

Fig. 9. Tipped petroleum tanks.

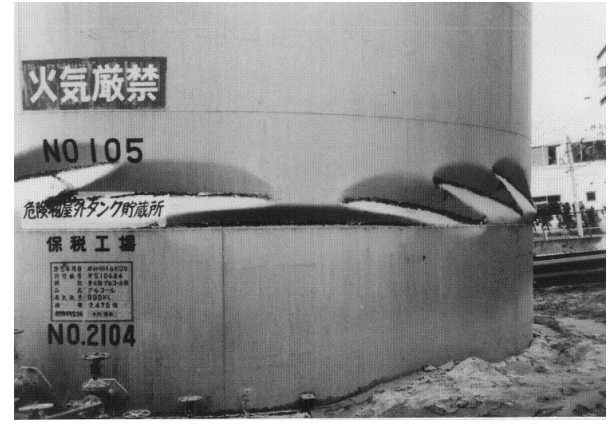

Fig. 10. Buckled alcohol tank wall.

\subsection{General Gas Manufacturing Installations}

Damage to gas facilities included 106 cases of leakage in medium-pressurized piping and 26,459 cases of leakage in low-pressurized piping. About 860,000 cases of gas stoppage also occurred.

The basic concept of design earthquake motions to gas installations is as follows:

Earthquake motion A: General earthquake motion that occurs one or twice during a service period.

Earthquake motion $B$ : High-level earthquake motion that occurs with less probability during a service period and that exceeds Earthquake motion $A$.

The target is to establish secure the seismic code of seismic gas installations as listed in Table 2 taking into account the effect of structures and facilities on human life, rescue operations, prevention of secondary disasters, and economic activity.

Table 2. Seismic code for general gas facilities.

\begin{tabular}{|l|l|l|}
\hline & $\begin{array}{l}\text { Earthquake motion } A \\
\text { (general earthquake motion) }\end{array}$ & $\begin{array}{l}\text { Earthquake motion } B \\
\text { (high-level earthquake motion) }\end{array}$ \\
\hline $\begin{array}{l}\text { Facilities largely affected if an } \\
\text { earthquake occurs. (e,g.,) storage } \\
\text { tanks, high-pressure gas pipes. }\end{array}$ & $\begin{array}{l}\text { No damage, operation, motion } \\
\text { can be restarted immediately } \\
\text { without repair. }\end{array}$ & $\begin{array}{l}\text { Structures may be deformed, but } \\
\text { no collapse or leakage occurs, } \\
\text { lowering the chance of danger to } \\
\text { people. }\end{array}$ \\
\hline $\begin{array}{l}\text { Other facilities (e.g.,) gas gener- } \\
\text { ation facilities, low voltage gas } \\
\text { pipes. }\end{array}$ & $\begin{array}{l}\text { No damage or minor damage } \\
\text { may possibly occur, but most } \\
\text { functions remain enabled. }\end{array}$ & $\begin{array}{l}\text { Function as a structure is lost, but } \\
\text { damage is minimized. }\end{array}$ \\
\hline
\end{tabular}

\section{Damage to High-Pressure Gas Facilities and Revision of Seismic Design Code}

As damage due to the Kobe earthquake became apparent, the seismic design codes for different structures were reviewed and revised. Some parts of seismic codes were also revised for production and energy installations. This chapter picks up a high-pressure gas (HPG) facility as an example of these installations. 


\subsection{Damage to High-Pressure Gas Facilities}

The Kobe earthquake, which struck on January 17, 1995, caused no human loss due to the failure of HPG facilities, but these facilities were damaged as shown in Table 3. The leakage of liquefied petroleum from a storage tank on the southern coast of Kobe was the most notable damage to HPG facilities, and it caused a large amount of LP-gas in the liquid phase, to leak from the inlet/outlet piping flange connection of an LP-gas storage system. On January 18, as leakage increased with aftershocks, 70,000 residents living nearby were advised by Kobe Disaster Headquarters to evacuate.

Immediately after the earthquake, liquefaction in the area, covered the entire site with muddy water 0.3 to $0.4 \mathrm{~m}$ deep. Ground throughout the site sank vertically and was displaced horizontally toward the sea. The maximum ground settlement was $0.8 \mathrm{~m}$ and of horizontal displacement $1.5 \mathrm{~m}$ in the area closest to the south shore. The concrete structures for shore protection tilted and were displaced toward the sea by about $3 \mathrm{~m}$. The concrete dike surrounding HPG tanks sank about $0.6 \mathrm{~m}$ with inclination. Lateral ground displacement broke open dike joints to a maximum of $0.6 \mathrm{~m}$.

Liquid LP-gas leaked from the stop valve and inlet/outlet piping nozzle of Tank No. 101 which was a flat-bottomed cylindrical double-shell tank with a capacity of $20,000 \mathrm{kl}$ and stock of $6,700 \mathrm{kl}$ at the time of the incident.

Leakage occurred as follows. Due to ground

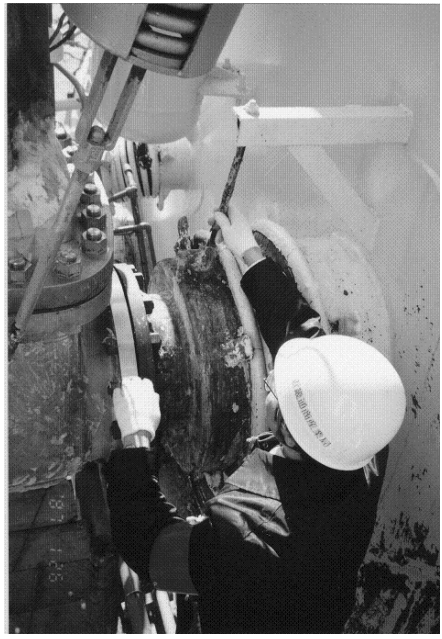

Fig. 11. LP gas leakage portion at the connection of flange. liquefaction, 0.5 to $0.8 \mathrm{~m}$ vertical ground settlement caused the LP-gas to leak from the nozzle flange connection between the tank and piping pulled seaward (Fig.11).

Table 3. Number of HPG facilities damaged.

\begin{tabular}{|l|c|c|}
\hline \multicolumn{1}{|c|}{ Facilities } & Damage mode & Number \\
\hline $\begin{array}{l}\text { Equipments for produc- } \\
\text { tion, Equipments for con- } \\
\text { sumption, etc. }\end{array}$ & incline, subside & 13 \\
\hline Storage tanks & incline, subside & 22 \\
\hline Piping & deformation, broken & 16 \\
\hline Refrigeration equipments & breaking & 9 \\
\hline Dikes, Water sprays etc. & breaking & 20 \\
\hline
\end{tabular}

\subsection{Overview of New Seismic Design Code for High-Pressure Gas Facilities}

Based on lessons from the Kobe Earthquake, the Seismic Design Code was amended in Notification No. 143 on March 25, 1997, after reviews and investigations by the "Seismic Safety Promotion Committee" set up in The High-Pressure Gas Safety Institute of Japan under the charge of the former METI, the Ministry of Economy, Trade and Industry. The main items of the new code for HPG facilities are as follows:

Introduction of Two-Step Earthquake Assessments. The Basic Plan for Disaster Prevention revised by the Central Disaster Prevention Council, July 1995, requires "two-step earthquake assessments." Level 1 earthquakes and Level 2 earthquakes are defined and the required seismic performances is stipulated.

Seismic Design Code for Liquefaction of Ground. Regarding foundations, damage is due to ground liquefaction. The required performance against ground liquefaction is added to the Seismic Design Code.

Seismic Design Code for Piping Systems. Regarding piping, which was beyond the scope of the previous Seismic Design Code, because some damage was incurred, the 
seismic required performance of piping is added in the new code.

Level 1 Required Seismic Performance. Seismic design structures shall maintain "Level 1 Required Seismic Performance" in the event of a Level 1 earthquake. For HPG facilities not to lose their functions during Level 1 earthquakes, the Level 1 Required Seismic Performance (L1-RSP) of seismic design structures is defined so that HPG facilities incur no fatal residual deformation and no persisting leakage of HPG during and after the Level-1 Earthquake.

Level 2 Required Seismic Performance. Seismic design structures shall maintain "Level 2 Required Seismic Performance in the event of Level 2 earthquakes."

For damaged HPG facilities to have no serious effect on public, properties and environment in a Level 2 earthquake, the Level 2 Required Seismic Performance (L2-RSP) of seismic design structure is defined so that HPG facilities incur no leakage of HPG during and after Level 2 earthquake. For HPG facilities, nonelastic deformation due to L2 earthquake is allowed to the extent that it does not induce gas leakage. Operations of HPG facilities shall not be restarted after a Level 2 earthquake without checking or reviewing safety.

Allowable deformations shall be determined so that there is no leakage of HPG considering failure modes of individual seismic structures. The failure mode of items for evaluating $L 2-R S P$ are the same as that for evaluating $L 1-R S P$.

\section{Development of Advanced Seismic Dampers}

To maintain the high performance of structures, machinery, equipments and piping systems, many types of dampers such as elasto-plastic, adaptive, electrorheological, visco-elastic, and granular dampers have been proposed. Some were developed by Japanese industrial firms such as Hitachi, IHI, and Mitsubishi, and others were developed by joint projects among governmental, academic, and industrial sectors.

A typical example of the cooperative work for developing damping devices is a national project monitored by the Nuclear Power-plant Engineering Commission (NUPEC ${ }^{*}$ )under the sponsorship of METI. In this project, two stages of seismic providing tests were done for nuclear piping with damper systems using the large two-dimensional shaking table at Tadotsu, Kagawa Prefecture. In the first stage, testing was done on a piping system having conventional supports such as the hydraulic dampers and the mechanical snubbers. In the second stage, testing was done on piping systems with supports developed by industrial firms as seismic energy absorbers. Energy absorbers such as the elastoplastic absorber (EAB) developed by Hitachi group and lead excursion damper (LED) developed by Mitsubishi were used (Figs.12 and 13).

This project confirmed that nuclear pipings having conventional supports such as snubbers could maintain enough strength against the excessive design seismic excitations. It was also recognized that newly developed energy absorbers such as EAB and LED could be introduced in place of conventional supports for plants in the near future. The number of snubbers can be greatly reduced since individual EAB or LED absorb much more seismic energy. After the project, NUPEC conducted this research to develop absorbers, piping systems and heavy mechanical nuclear equipment such as PWR steam generators (Fig.14).

There has been increasing research in several industrial fields for the development of semiactive vibration control devices. Devices using magneto-rheological fluid (MR fluid) have attracted great research interest because they realize high performance as capacity variable dampers. MR

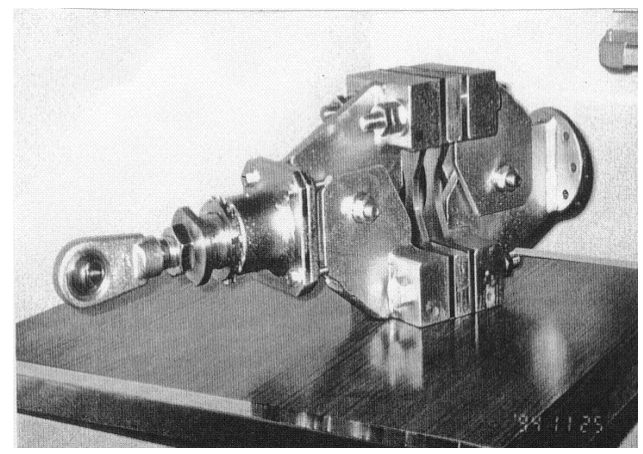

Fig. 12. Elasto-plastic seismic energy absorber (EAB) for the piping system developed by Hitachi and Toshiba Corporations. 
fluids are controllable responding to applied magnetic fields, which dramatically change the viscosity of MR fluids from oily to semi-solid state.

Figure 15 shows large capacity seismic MR damper developed by Sanwa Tekki Corporation. Table 4 shows design specifications of the MR damper. Magnetic flux penetrates the MR fluid flow perpendicularly, as detailed in Fig.15. These MR dampers were first installed in Japan (Fig.16).

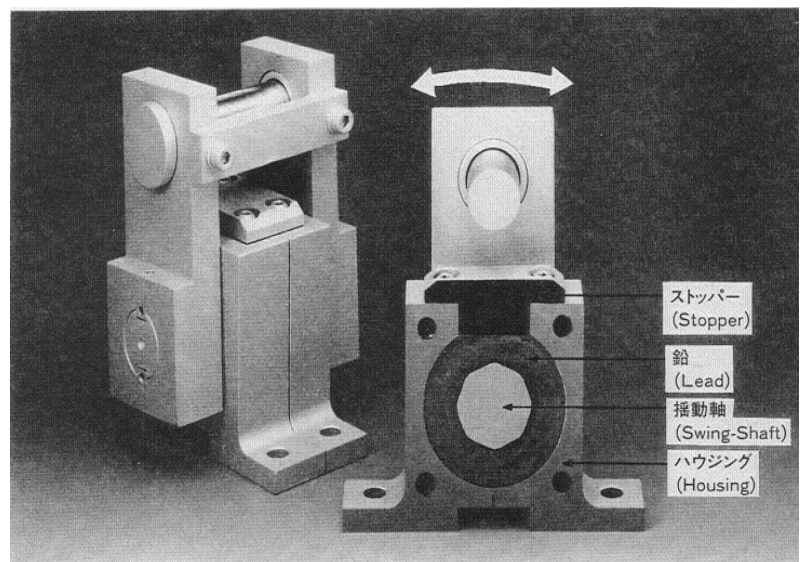

Fig. 13. Lead excursion damper (LED) for the piping system developed by Mitsubishi Heavy Industries.

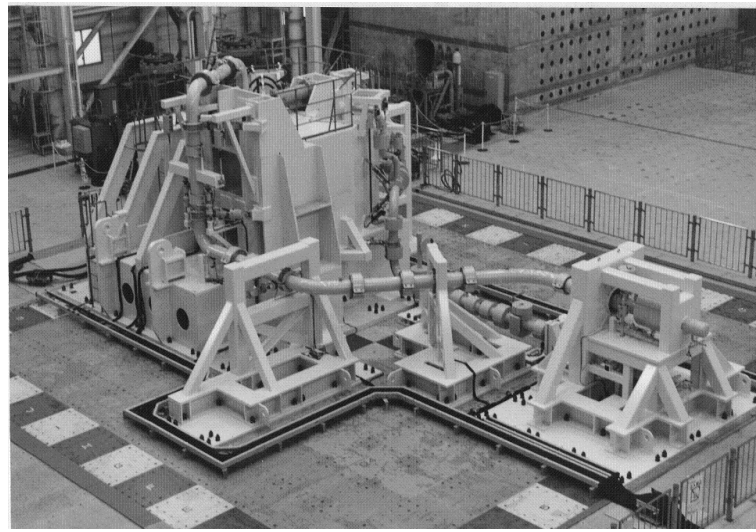

Fig. 14. Seismic proving test of nuclear pipings with EAB and LED on Tadotsu shaking table.

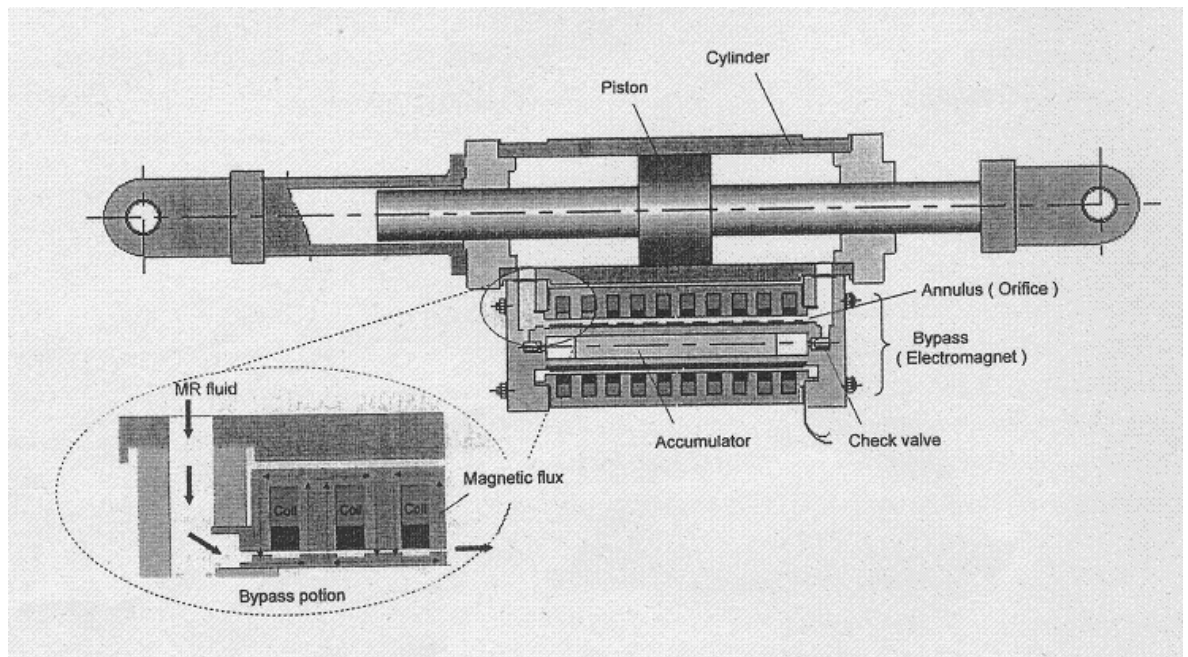

Fig. 15. Large capacity MR damper. 


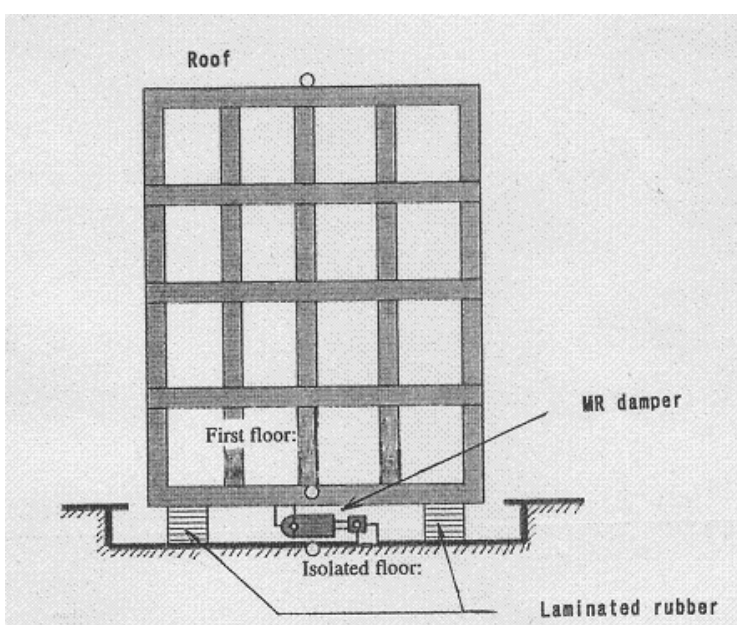

Fig. 16. Schematic view of seismic isolated building by using MR damper.

Table 4. Design specifications of MR damper.

\begin{tabular}{|c|cc|}
\hline Rated Load & \multicolumn{2}{|c|}{$300 \mathrm{kN}$} \\
\hline Stroke & \multicolumn{2}{|c|}{$240 \mathrm{~mm}( \pm 120 \mathrm{~mm})$} \\
\hline Cylinder boree & \multicolumn{2}{|c|}{$155 \mathrm{~mm}$} \\
\hline Piston rod dia. & \multicolumn{2}{|c|}{$70 \mathrm{~mm}$} \\
\hline Bypass orifice & Outer & $48 \mathrm{~mm}$ \\
& diameter & $45 \mathrm{~mm}$ \\
& $\begin{array}{c}\text { Lnner diameter } \\
\text { MR fluid }\end{array}$ & $200 \mathrm{~mm}$ \\
\hline Electromagnet & Congth MRF-132L D \\
& Inductance & 272 turns x 10 \\
& Resistance & $60 \mathrm{mH}$ \\
& \multicolumn{2}{|c|}{$10 \mathrm{ohms}$} \\
\hline
\end{tabular}

\section{Development of Large Seismic Experimental Facility}

The 1995 Kobe earthquake made people recognize anew the destruction of structures by earthquake motion and the need for further development of seismic technology. Many organizations and academic societies pointed out the importance of clarifying how large structures and buildings are actually be destroyed. At their request, a national project was planned that constructed a large experimental facility for destruction by shaking, which forcibly excites an actual-size structure. The National Research

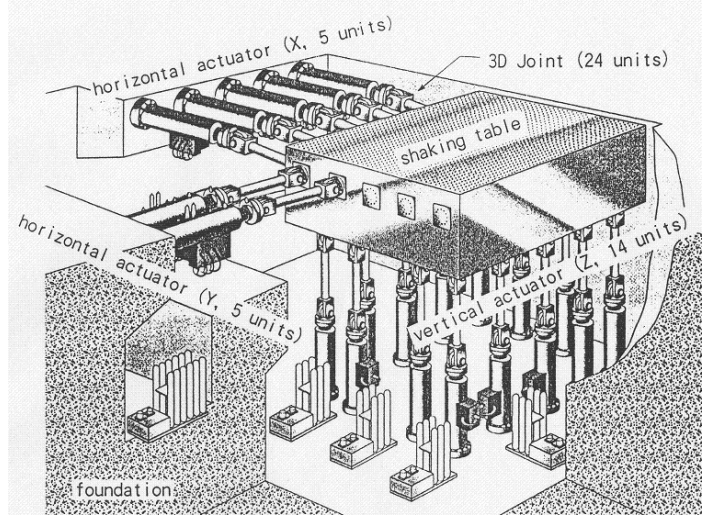

Fig. 17. 3 dimensional, large-scale shaking table.

Institute for Earth Science and Disaster Prevention (NIED) and the Science and Technology Agency of the Japanese Government (STA) started to plan and design the experimental facility in 1995 and launched its construction in 1998. This facility was constructed in Miki of the Hyogo Prefecture, near Kobe, and completed in January 2005, the 10th year just after the earthquake disaster. 
Figure 17 shows the shaking table that is a major component of the actual-size 3D shaking destruction experimental facility. Table 5 lists basic specifications of this shaking table. Research projects using this experimental facility were started from 2006 and shaking destruction mechanisms are now under study for structural steel works, existing wooden structures, and foundations. Shaking experiments are consecutively planned on seismic isolated building structures and seismic reinforced structures. It is expected that destruction mechanisms of different structures due to earthquakes will be solved including international projects.

Table 5. Basic specifications of the shaking table.

\begin{tabular}{|c|c|c|}
\hline & horizontal ( $\mathrm{X}$ and $\mathrm{Y})$ & vertical $(Z)$ \\
\hline table size & \multicolumn{2}{|l|}{$15 \mathrm{~m} \times 20 \mathrm{~m}$} \\
\hline maximum test weight & \multicolumn{2}{|l|}{1200 tonf } \\
\hline drive direction & \multicolumn{2}{|c|}{$\mathrm{X}, \mathrm{Y}, \mathrm{Z}$ translation and rotation } \\
\hline drive mechanism & \multicolumn{2}{|c|}{ accumulator charge/electro-hydraulic servocontrol } \\
\hline maximum displacement & $\pm 100 \mathrm{~cm}$ & $\pm 50 \mathrm{~cm}$ \\
\hline maximum velocity & $200 \mathrm{~cm} \mathrm{~s}^{-1}$ & $70 \mathrm{~cm} \mathrm{~s}^{-1}$ \\
\hline \multicolumn{3}{|l|}{ (at maximum test weight) } \\
\hline maximum overturning moment & \multicolumn{2}{|c|}{$\geqq 15000$ tonf $\mathrm{m}$ (at $\mathrm{Z}=1 \mathrm{~g})$} \\
\hline maximum yawing moment & \multicolumn{2}{|c|}{$\geqq 4000$ tonf $\mathrm{m}$ (at maximum horizontal acceleration) } \\
\hline maximum rotation & \multicolumn{2}{|c|}{$2.5^{\circ}($ around $\mathrm{X}, \mathrm{Y}$ or $\mathrm{Z})$} \\
\hline frequency & \multicolumn{2}{|c|}{$0-15 \mathrm{~Hz}$ (with accuracy) $15-30 \mathrm{~Hz}$ (can be driven) } \\
\hline wave distortion & \multicolumn{2}{|c|}{$\leqq 15 \%$ (in useful domain) } \\
\hline
\end{tabular}

\section{Conclusion}

We have presented an overview of the seismic design methods and vibration control technology triggered based on damage to industrial facilities by the 1996 Kobe (HanshinAwaji) earthquake.

With industrial advances, the facilities and systems that we deal with have been larger in scale and more complex in combination. In response to this trend, technology to protect against earthquakes is expected to make ongoing.

Damage due to earthquakes contains valuable lessons that must be implement in the establishment of measures effective against earthquakes.

\section{References}

(1) H. Shibata, K. Suzuki, and M. Ikeda, "Development of Seismic Design Code for HighPressure Gas Facilities in Japan," ASME Journal of Pressure Vessel Technology, Vol.126, pp. 2-8, 2004.

(2) H. Sodeyama, K. Sunakoda, and K. Suzuki, "Development of Large Capacity Semi-Active Seismic Damper Using Magneto-Rheological Fluid," ASME Journal of Pressure Vessel Technology, Vol.126, pp. 105-109, 2004.

(3) K. Suzuki, G. R. Reddy, and S. C. Mahajan, "The Great Hanshin Earthquake of January 17, 1995," Bulletin of Indian Society of Earthquake Engineering, Vol.32, No.4, pp. 127-146, 1995.

(4) K. Suzuki, "Report on Damage to Industrial Facilities in the 1999 Kocaeli Earthquake, Turkey," Journal of Earthquake Engineering, Vol.2, N0.2, pp. 275-296, 2002. 